\title{
Studi Kasus: Asuhan Keperawatan Jiwa Pada Ny. M Dengan Masalah Halusinasi di Jalan Lizadri Putra
}

\author{
May Thent Gustavian Daeli
}

\author{
Vianydaeli778@gmail.com
}

\section{BAB 1}

\section{PENDAHULUAN}

\subsection{Latar Belakang}

Skizofrenia adalah suatu gangguan jiwa yang ditandai dengan penurunan atau ketidakmampuan berkomunikasi, gangguan realita (halusinasi dan waham), afek yang tidak wajar atau tumpul, gangguan kognitif (tidak mampu berfikir dan mengalami kesukaran melakukan aktivitas sehari-hari. Seorang yang mengalami skizofrenia terjadi kesulitan berfikir dengan benar, memahami dan menerima realita, gangguan emosi/perasaan, tidak mampu membuat keputusan, serta gangguan dalammelakukan aktivitas atau perubahan perilaku. Klien skizofrenia $70 \%$ mengalami halusinasi (Pardede et al, 2021). Skizofrenia yang berasal dari bahasa yunani yakni "Skhizein" yang dapat diartikan retak atau pecah (split), dan "phren" yang berarti pikiran, yang selalu dihubungkan dengan fungsi emosi. Masalah yang sering muncul pada pasien skizofrenia adalah halusinasi (Pardede, 2017)

Halusinasi merupakan keadaan seseorang mengalami perubahan dalam pola dan jumlah stimulasi yang diprakarsai secara internal atau eksternal disekitar dengan Kekambuhan sebagai akibat dari regimen teraupetik tidak efektif dapat lebih parah dan bahaya dari pada klien gangguan awitan awal (Pardede \& Siregar 2016). Halusinasi merupakan persepsi yang salah (false perception) tanpa adanya objek luar. Tentu saja persepsi yang dihasilkan tidak seperti persepsi yang normal, ada objek luar pembentuk persepsi. Selain itu halusinasi hanya dimiliki oleh individu tersebut, sedangkan orang lain tidak memilikinya. Halusinasi dapat diperngaruhi oleh imajinasi mental yang kemudian diproyeksikan keluar sehingga seolah-olah datangya dari luar dirinya, sehingga orang yang mengalami halusinasi sangat berdampak buruk (Nurdiana 2020).

Pada pasien skizofrenia berpengaruh pada masalah yaitu kegagalan dalam berpikir yang mengakibatkan pasien tidak mampu memproses dan mengatur pikirannya. Kebanyakan pasien tidak mampu memahami hubungan antara kenyataan dan logika. Mereka yang 
menderita skizofrenia berbicara asal atau serampangan dan tidak bisa ditangkap secara logika oleh orang yang normal. Ketidakmampuan pasien skizofrenia dalam berpikir mengakibatkan tidak bisa mengendalikan emosi dan perasaan. Hasilnya, kadang penderita skizofrenia tertawa sendiri tanpa sebab dan berbicara sendiri dengan keras tanpa mempedulikan sekelilingnya, (Restia Putri \& Ema 2020)

Survei awal pada pembuatan askep pada skizofrenia ini dilakukan di Jalan Lizadri Putra Kecamatan Medan Tuntungan yang ditemukan pasien gangguan sensori persepsi : halusinasi atas nama inisial Ny.M yang pernah di rawat di RSJ. 3 Penyebabnya Ny.M dijadikan subjek dikarenakan Ny.L belum sepenuhnya bisa mengatasi halusinasinya. Maka tujuan asuhan keperawatan yang akan di lakukan ialah untuk mengajarkan standar pelaksanaan gangguan sensori persepsi : halusinasi atau cara menghardik halusinasi pada Ny.M.

\subsection{Rumusan Masalah}

Berdasarkan latar belakang masalah tersebut maka dapat dirumuskan masalah sebagai berikut : Bagaimana Memberikan Asuhan Keperawatan Jiwa Dengan Masalah Halusinasi Pada Tn.L Di Jalan Lizadri Putra Kecamatan Medan Tuntungan

\subsection{Tujuan}

\subsubsection{Tujuan Umum}

Memberikan asuhan keperawatan jiwa pada Ny.M dengan halusinasi di Jalan Lizadri Putra Kecamatan Medan Tuntungan

\subsubsection{Tujuan Khusus}

a) Mahasiswa mampu mengetahui defenisi, tanda dan gejala, faktor penyebab, mekanisme koping, penatalaksanaan pada pasien dengan Gangguan Sensori Persepsi : Halusinasi

b) Mahasiswa mampu melakukan pengkajian pada pasien dengan Gangguan Sensori Persepsi : Halusinasi

c) Mahasiswa mampu menegakkan diagnosa atau masalah keperawatan pada Ny.M dengan Gangguan Sensori Persepsi : Halusinasi

d) Mahasiswa mampu menetapkan intervensi keperawatan secara menyeluruh pada Ny.L dengan Gangguan Sensori Persepsi : Halusinasi

e) Mahasiswa mampu melakukan tindakan keperawatan yang nyata pada Ny.M dengan Gangguan Sensori Persepsi : Halusinasi

f) Mahasiswa mampu mengevaluasi sebagai tolak ukur guna menerapkan asuhan keperawatan pada Ny.M dengan Gangguan Sensori Persepsi : Halusinasi

g) Mahasiswa mampu mendokumentasikan asuhan keperawatan pada Ny.M dengan Gangguan Sensori Persepsi : Halusinasi 


\section{BAB 2}

\section{LANDASAN TEORI}

\subsection{Isolasi Sosial}

\subsubsection{Pengertian}

Halusinasi merupakan keadaan seseorang mengalami perubahan dalam pola dan jumlah stimulasi yang diprakarsai secara internal atau eksternal disekitar dengan pengurangan, berlebihan, distorsi, atau kelainan berespon terhadap setiap stimulus (Pardede et al, 2021). Halusinasi adalah suatu kejadian melihat, mendengar, menyentuh, mencium, ataupun merasakan sesuatu tanpa adanya rangsangan eksternal terhadap organ sensori. Pada beberapa rumah sakit jiwa di Indonesia didapati bahwa $70 \%$ nmengalami halusinasi yang dialami oleh pasien gangguan jiwa adalah halusinasinsuara (20\%) halusinasi lihat (30\%) dan adalah halusinasi penciuman pengecapan dn perabaan (10\%). (Prakoso, 2020)

Halusinasi adalah gangguan penerimaan pancaindra tanpa stimulasi eksternal (halusinasi pendengaran, penglihatan, pengecapan, penciuman, dan perabaan). Halusinasi merupakan salah satu gejala gangguan jiwa pada individu yang di tandai dengan perubahan sensori persepsi; merasakan sensasi palsu berupa suara, penglihatan, pengecapan perabaan atau penghiduan. Pasien merasakan stimulus yang sebenarnya tidak ada. (Emulyani, 2020)

\subsubsection{Tanda dan Gejala}

Menurut Pima Astari (2010) tanda dan gejala halusinasi sebagai berikut :

a. Menarik diri dari orang lain, dan berusaha untuk menghindar diri dari orang lain

b. Tersenyum sendiri, tertawa sendiri

c. Duduk terpukau (berkhayal)

d. Bicara sendiri

e. Memandang satu arah, menggerakan bibir tanpa suara, penggerakan mata yang cepat, dan respon verbal yang lambat 
f. Menyerang, sulit berhubungan dengan orang lain

g. Tiba-tiba marah,curiga, bermusuhan, merusak (diri sendiri, orang lain dan lingkungan ) takut

h. Gelisah, ekspresi muka tegang, mudah tersinggung, jengkel,

i. Terjadi peningkatan denyut jantung, pernapasan dan tekanan darah

Tanda dan gejala skizofrenia yang dapat terjadi pada klien dengan halusinasi adalah sebagai berikut: Terjadi peningkatan frekuensi pernapasan dan nadi, muka merah, sulit tidur serta ekspresi wajah tampak tegang dan berkeringat, kadang merasa ketakutan, mudah tersinggung, jengkel, merasa curiga, serta mudah marah, klien dengan halusinasi mengalami penurunan kemampuan secara kognitif, klien lebih banyak berbicara, senyum dan tertawa sendiri, klien juga mengatakan mendengar suara, melihat, menghirup, mengecap dan merasa sesuatu yang tidak nyata, gejala yang tampak meliputi sikap curiga dan bermusuhan sehingga klien dapat menarik diri dari lingkunganya (Pardede, Keliat \& Wardani, 2013)

\subsubsection{Etiologi}

Proses terjadinya halusinasi dijelaskan dengan menggunakan konsep stress adaptasi stuart yang meliputi stressor dari faktor predisposisi dan presipitasi. Selain itu halusinasi juga dapat disebabkan karena isolasi sosial yang dapat mengakibatkan halusinasi dan akan berdampak pada resiko perilaku kekerasa. (Restia. 2020)

\section{Faktor Predisposisi}

a) Faktor Biologis

Adanya riwayat anggota keluarga yang mengalami gangguan jiwa (herediter), riwayat penyakit atau trauma kepala, dan penggunaan narkotika, psikotropika, dan zat adiktif lain.

b) Faktor Psikologis 
Memiliki riwayat kegagalan yang berulang. Menjadi korban, pelaku maupun saksi dari perilaku kekerasan serta kurangnya kasih sayang dari orang-orang sekitar atau keluarga atau overprotektif.

c) Sosial Budaya Dan Keluarga

Sebagian besar pasien halusinasi berasal dari keluarga dengan sosial ekonomi rendah, selain itu pasien memiliki riwayat penolakan dari lingkungan pada usia perkembangan anak, pasien halusinasi seringkali memiliki tingkat pendidikan yang rendah serta pernah mengalami kegagalan dalam hubungan sosial (percerain, hidup sendiri) serta tidak bekerja.

\section{Faktor Presipitasi}

Menurut Stuart dan Sudeen faktor presipitasi dapat meliputi (Prabowo, 2014) :

a) Biologis

Gangguan dalam komunikasi dan putaran balik otak, yang mengatur proses informasi serta abnormalitas pada mekanisme pintu masuk dalam otak yang mengakibatkan ketidakmampuan untuk secara selektif menanggapi stimulus yang diterima oleh otak untuk diinterpreta sikan.

1. Stress lingkungan

Ambang toleransi terhadap stress yang berinteraksi terhadap stressor lingkungan untuk menentukan terjadinya gangguan perilaku.

2. Sumber koping

Sumber koping mempengaruhi respon individu dalam menanggapi stressor.

\subsubsection{Rentang Respon Adaptif Neurologis}

\section{Respon Adaptif $\longleftrightarrow$ Respon Maladaptif}

\begin{tabular}{|l|l|l|}
\hline \multicolumn{1}{|c|}{$\downarrow$} & \multicolumn{1}{|l|}{$\downarrow$} \\
\hline $\begin{array}{ll}\text { Emosi konsisten } \\
\text { Pikiran logis Persepsi } \\
\text { akurat Perilaku sesuai } \\
\text { Hub. Sosial harmonis }\end{array}$ & $\begin{array}{l}\text { Proses pikir terkadang ter- } \\
\text { ganggu ilusi Emosi ber- } \\
\text { lebihan/kurang Perilaku } \\
\text { tidak terorganisir Isolasi } \\
\text { sosial }\end{array}$ & $\begin{array}{l}\text { Proses pikir terjadi } \\
\text { waham halusinasi } \\
\text { Kerusakan proses } \\
\text { emosi Perilaku tidak } \\
\text { sesuai }\end{array}$ \\
\hline
\end{tabular}




\subsubsection{Penatalaksanaan Medis}

Tindakan keperawatan untuk membantu klien mengatasi halusinasinya dimulai dengan membina hubungan saling percaya dengan klien. Hubungan saling percaya sangat penting dijalin sebelum mengintervensi klien lebih lanjut. Pertama-tama klien harus difasilitasi untuk merasa nyaman menceritakan pengalaman aneh halusinasinya agar informasi tentang halusinasi yang dialami oleh klien dapat diceritakan secara konprehensif. Untuk itu perawat harus memperkenalkan diri, membuat kontrak asuhan dengan klien bahwa keberadaan perawat adalah betul- betul untuk membantu klien. Perawat juga harus sabar, memperlihatkan penerimaan yang tulus, dan aktif mendengar ungkapan klien saat menceritakan halusinasinya. Hindarkan menyalahkan klien atau menertawakan klien walaupun pengalaman halusinasi yang diceritakan aneh dan menggelikan bagi perawat. Perawat harus bisa mengendalikan diri agar tetap terapeutik. (Pardede, 2020)

\subsection{Konsep Asuhan Keperawatan}

\subsubsection{Pengkajian}

Pengkajian merupakan tahap awal dan dasar utama dari proses keperawatan yang sistematis dari pengumpulan data dari berbagai sumber untuk mengevaluasi dan mengidentifikasi simetris keadaan pasien. (Feri, 2020)

\subsubsection{Diagnosa}

Menurut NANDA 2015-2017 yakni gangguan persepsi. Dengan faktor berhubungan dan batasan karakteristik disesuaikan dengan keadaan yang ditemukan pada tiap-tiap partisipan. Topik yang diteliti yakni kemampuan mengontrol halusinasi dengar. (Damayanti, 2014) 


\subsubsection{Intervensi Keperawatan}

Perencanaan keperawatan adalah serangkaian tindakan yang dapat dilaksanakan untuk mencapai tujuan khusus. Rencana keperawatan yang digunakan yaitu dengan cara pemberian teknik mengontrol halusinasi dengan pemberian sp 1

a. mengidentifikasi isi, frenkuensi, waktu terjadi, situasi pencetus, respon halusinasi. b. Mengontrol halusinasi dengan menghardik. Sp 2 Mengontrol halusinasi dengan minum obat secara teratur. Sp 3 Mengontrol halusinasi dengan bercakapcakap dengan orang lain. Sp 4 Mengontrol halusinasi dengan melakukan kegiatan terjadwal. (Cressela, 2020)

\subsubsection{Penatalaksanaan Keperawatan}

Pada diagnosa keperawatan halusinasi pendengaran maka dilakukan tindakan keperawatan dengan cara melakukan strategi pelaksanaan. Strategi pelaksanaan tindakan keperawatan: 1 . SP 1 pasien: mengenal halusinasi pada pasien, menjelaskan caracara mengontrol halusinasi, mengajarkan pasien cara mengontrol halusinasi dengan cara yang pertama yaitu: menghardik halusinasi. 2. SP 2 pasien : melatih pasien menggunakan obat secara teratur 3. SP 3 pasien : melatih pasien mengontrol halusinasi dengan cara ketiga : bercakap-cakap dengan orang lain. 4. SP 4 pasien : melatih pasien mengontrol halusinasi dengan cara keempat : melaksanakan aktifitas terjadwal. (Restia, 2020)

\subsubsection{Evaluasi Keperawatan}

Evaluasi yang dilakukan pada klien adalah menggunakan evaluasi formatif yang dilakukan setiap harinya. Pada evaluasi ini data yang didapat pada klien yaitu klien masih mendengar suara yang memanggil namanya dan menyuruhnya bekerja dengan frekuaensi mulai berkurang dalam sehari yaitu 3 kali dalam sehari. Selain itu klien mampu mengontrol halusinasinya dengan cara menghardik dan cara mengontrol halusinasi dengan cara patuh minum obat. Pada strategi pelaksanaan klien di ajarkan cara menghardik dan patuh minum obat agar klien mampu mengontrol halusinasi yang dialaminya (Dalami, 2014) 


\section{BAB 3}

\section{TINJAUAN KASUS}

\subsection{Identitas Klien}

$\begin{array}{lll}\text { Inisial } & : & \text { Ny. M } \\ \text { Jenis kelamin } & : & \text { Perempuan } \\ \text { Umur } & : & 28 \text { Tahun } \\ \text { Agama } & : & \text { Kristen Prosestan } \\ \text { Status } & : & \text { Belum Menikah } \\ \text { Tanggal pengkajian } & : & 6 \text { Maret 2021 } \\ \text { Informan } & : & \text { Status klien dan komunikasi dengan klien }\end{array}$

\subsection{Keluhan}

Pasien sering berbicara dan tertawa sendiri, pasien juga sering menangis ketakutan, dan selalu bersembunyi karena ketakutan sering mendengar suarasuara aneh. Ketika Pasien pertama kali masuk kerumah sakit pasien sempat mengurung diri dan tidak ingin berkomunikasi dengan orang lain.

\subsection{Faktor Predisposisi}

Pasien sebelumnya tidak ada riwayat gangguan jiwa. Pada pertama kali pasien mengalami gangguan jiwa ketika colon suami pasien telah meninggal dunia menjelang pernikahan mereka. Awalnya pasien dalam keadaan baik-baik saja. Namun ketika mendengar berita kematian calon suaminya, pasien akhirnya tidak berterima dan sempat marah-marah. Keluarga juga mengatakan pengobatan sebelumnya sudah ke Psikiater dan dukun, namun ketika kondisi pasien semakin memburuk akhirnya di bawa ke RSJ, dan selama kurang lebih 3 bulan, keadaan 
pasien tidak ada perubahan, akhirnya keluarga membawa pasien untuk pulang dan di rawat dirumah. Setelah 1 minggu di rawat dirumah, pasien pun sering menangis dan berteriak, dan kembali di bawa ke Psikiater. Dan setelah kurang lebih 2 minggu menjalankan pengobatan di Psikiater pengobatan dari Psikiater di hentikan karna keluarga pasien fokus untuk pengobatan tradisional. Pasien mengalami gangguan jiwa Kurang lebih 2 tahun. Selama 2 tahun pasien tidak pernah mengkonsumsi obat secara teratur lagi. Pasien sering mendengar suarasuara dari telinganya bahkan pasien sering berbicara dengan orang yang tidak tampak. Terkadang pasien tertawa ketika mendegarkan halusinasinya. Pasien juga seperti ada dunia lain. Keluarga pasien tidak ada yang pernah mengalami gangguan jiwa.

Masalah Keperawatan : Halusinasi pendengaran

\subsection{Fisik}

Klien tidak memiliki keluhan fisik, saat dilakukan pemeriksaan tanda-tanda vital, didapatkan hasil TD : $120 / 80 \mathrm{mmHg}$; $\mathrm{N}: 80 \mathrm{x} / \mathrm{i} ; \mathrm{S}: 36,8^{\circ} \mathrm{C}$; P : 18x/i. Klien memiliki tinggi badan $160 \mathrm{~cm}$ dan berat badan $82 \mathrm{Kg}$.

\subsection{Psikososial}

\subsubsection{Genogram}

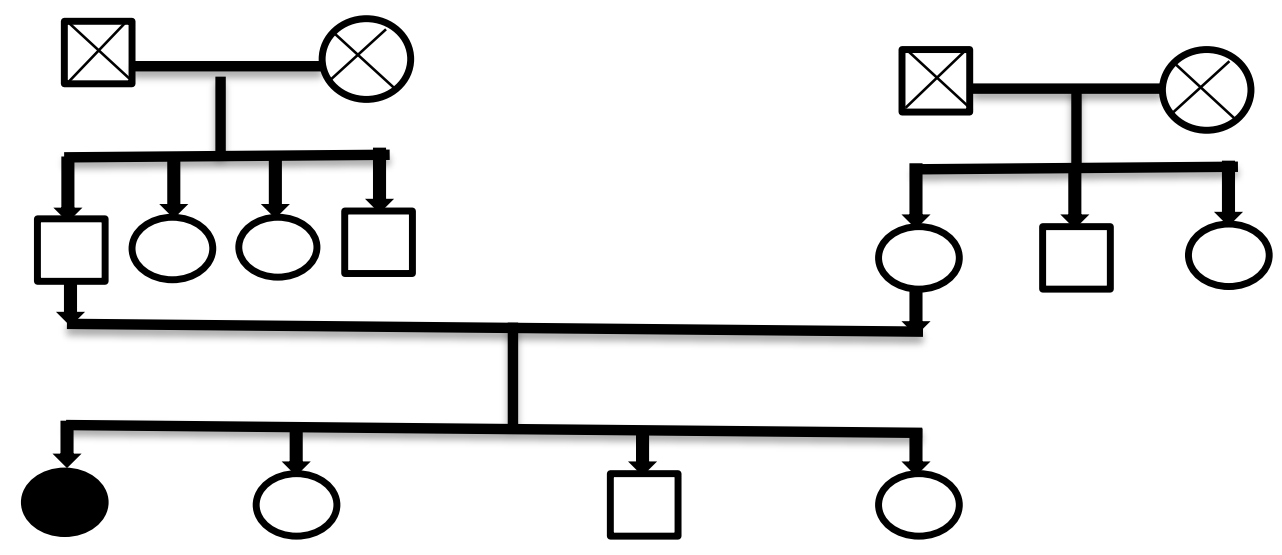


Klien tinggal di Jalan Lizadri putra, Kecamatan Medan Tuntungan Sumatera Utara. Klien mempunyai ayah satu dan ibu satu, serta mempunyai adik perempuan satu dua orang dan satu adik laki-laki. klien adalah anak Pertama dari empat bersaudara, klien mengalami gangguan jiwa dan keluarga dalam keadaan sehat fisik dan psikologis serta tidak mengalami gangguan jiwa (sehat jiwa).

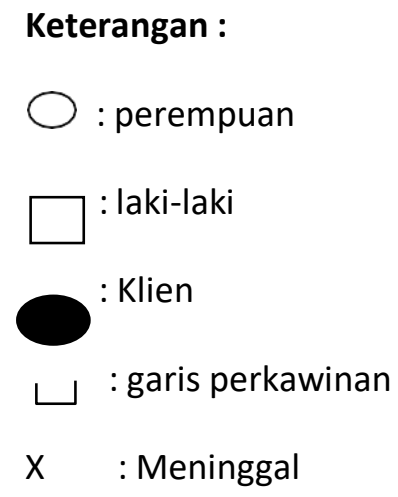

\subsubsection{Konsep Diri}

a. Gambaran diri : Klien mengatakan menyukai seluruh tubuhnya.

b. Identitas: Klien mengetahui dirinya sebagai anak ke 1 dari 4 bersaudara, klien lulusan Sarjana yang saat ini tidak memiliki pekerjaan dan mengatakan mengetahui keadaan penyakitnya saat ini.

c. Peran: Klien mengatakan mengetahui perannya sebagai anak karena klien sering mengerjakan pekerjaan rumah dan membantu ibunya dan menjadi kakak bagi adik-adiknya.

d. Ideal diri: Klien ingin segera sembuh dari penyakitnya agar bisa hidup seperti orang lain.

e. Harga diri: Klien mengatakan kurang percaya diri dan mudah putus asa. Klien merasa tidak berarti lagi dalam keluarganya Masalah Keperawatan : Harga Diri Rendah 


\subsubsection{Hubungan Sosial}

1. Orang yang terpenting : orang yang terpenting dalam hidup pasien adalahibu dan bapaknya

2. Peran serta dalam kegiatan kelompok/masyarakat : klien mengatakan ada ikut peran serta dalam keggiatan kelompok/masyarakat seperti di saat kegiatan 17 Agustus seperti lomba joget, klien dahulunya juga aktf dalam pelayanan gereja.

3. Hambatan dalam berbuhungan dengan orang Lain : klien mengatakan mengalami hambatan dalam berhubungan dengan orang lain karena partisipan memiliki sifat pendiam.

Masalah keperawatan : Isolasi Sosial.

\subsubsection{Spiritual}

1. Nilai dan Keyakinan : Klien beragama Kristen Prosestan dan yakin kepada Tuhan Ynang MahaEsa

2. Kegiatan Ibadah : Klien tidak pernah ibadah semenjak sakit

\subsubsection{Status Mental}

1. Penampilan

Klien tampak gigi dan mulut kotor, kuku tampak kotor dan rambut berantakan.

Masalah keperawatan : Defisit perawatan diri

2. Pembicaraan

Saat berbicara klien berbicara Lancar dan selalu menjawab jika ditanya

3. Aktivitas Motorik

Klien tampak biasa saja dan santai

4. Suasana perasaan

Klien tampak biasa saja seperti tidak ada masalah

5. Afek

Labil disaat ada suara bisikan klienberbicara sendiri, senyum-senyum sendiri, dan kadang gelisah 
Masalah keperawatan : Halusinasi pendengaran

6. Interaksi selama wawancara

Kooperatif dan mau menjawab pertanyaan-pertanyaan

7. Persepsi

Klien mengatakan sering mendengar suara-suara seperti mengajak dan menyuruh.

Masalah keperawatan : Gangguan persepsi sensori : halusinasi pendengaran.

8. Proses Pikir

Pembicaraan berhenti lalu di jelaskan kembali

Masalah keperawatan : Gangguan Proses Pikir

9. Isi pikir

Klien mengatakan selalu muncul fikiran yang menggangu dirinya.

Masalah Keperawatan : Gangguan isi pikir

10. Tingkat kesadaran

Klien tidak mengalami gangguan orientasi, klien mengenali waktu, orang dan tempat.

11. Memori

Klien mampu menceritakan kejadian dimasa lalu dan yang baru terjadi.

12. Tingkat konsentrasi berhitung

Klien mampu berkonsentrasi dalam perhitungan sederhana tanpa bantuan orang lain.

13. Kemampuan penilaian

Klien dapat membedakan hal yang baik danyang buruk,

14. Daya tilik diri

Klien mengatakan bahwa dirinya tidak mengerti dengan penyakitnya Masalah keperawatan : Kurangnya informasi. 


\subsection{Mekanisme Koping}

Klien mengalami mekanisme koping Maladptif yaitu klien bereaksi lambat dan menghindar.

\subsection{Masalah Psikososial dan Lingkungan}

Klien mengatakan sulit untuk berinteraksi dengan lingkungan sekitarnya.

\subsection{Pengetahuan Kurang Tentang Gangguan Jiwa}

Klien tidak mengetahui tentang penyakit gangguan jiwa dan klien tidak tahu obat apa yang harus diminum untuk mengatasi gangguan jiwanya.

\subsection{Analisa Data}

\begin{tabular}{|c|c|c|}
\hline No & Analisa Data & Masalah keperawatan \\
\hline 1 & $\begin{array}{l}\text { DS : } \\
\text { - Keluarga mengatakan klien } \\
\text { sering berbicara sendiri dan } \\
\text { tertawa sendiri } \\
\text { - Klien sering mendengar suara- } \\
\text { suara yang seperti mengajak } \\
\text { dan menyuruh hapir setiap hari. } \\
\text { - Klien terkadang menangis } \\
\text { ketika mendengar suara-suara } \\
\text { yang ia dengarkan. } \\
\text { - Klien sering mendengar suara- } \\
\text { suara ketika pagi hari sekitar } \\
\text { pukul 02.00 Wib. } \\
\text { DO : } \\
\text { - Klien tampak bingung. } \\
\text { - Kontak mata klien kurang saat } \\
\text { dilakukan wawancara. } \\
\text { - Di saat di lakukan wawancara } \\
\text { klien tiba-tiba berhenti } \\
\text { berbicara dan kembali } \\
\text { melanjutkan pembicaraan. }\end{array}$ & $\begin{array}{c}\text { Gangguan persepsi sensori: } \\
\text { Halusinasi : Pendengaran }\end{array}$ \\
\hline
\end{tabular}




\begin{tabular}{|l|l|l|}
\hline 2 & DS : & Risiko perilaku kekerasan \\
- Klien mengatakan mudah & \\
marah jika kehendaknya & \\
ataupun keinginannya tidak & \\
dipenuhi. & \\
- Keluarga klien mengatakan, \\
bahwa klien terkadang Egois \\
dengan keinginannya tidak mau \\
dilarang.
\end{tabular}

\begin{tabular}{|c|c|c|}
\hline & \begin{tabular}{|l} 
DO : \\
- \\
Klien tampak mudah \\
tersinggung dan suka curiga \\
dengan orang lain
\end{tabular} & \\
\hline 3 & \begin{tabular}{|l} 
DS : \\
- Klien mengatakan dahulunya \\
klien di jauhi oleh teman- \\
temannya karena klien \\
pendiam. \\
- Klien mengatakan bahwa \\
dirinya kurang berkomunikasi \\
dan berinteraksi dengan orang \\
lain. \\
DO : \\
- Klien tampak menyendiri \\
- Klien tampak berbicara lambat \\
dan membisu.
\end{tabular} & Isolasi Sosial \\
\hline
\end{tabular}




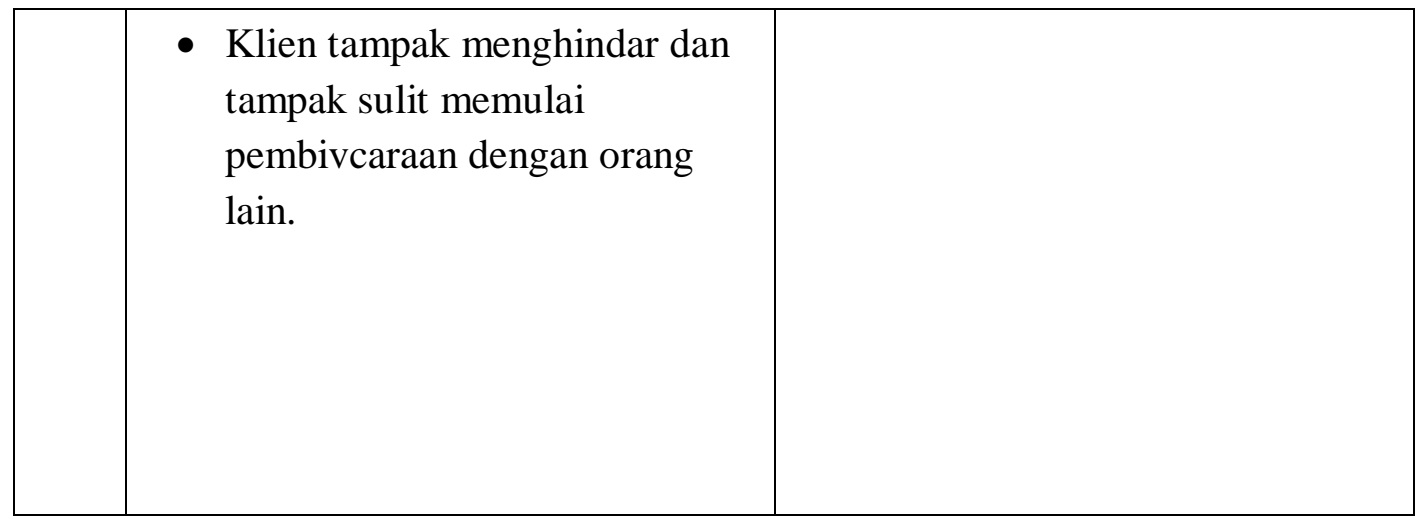




\subsection{Pohon Masalah}

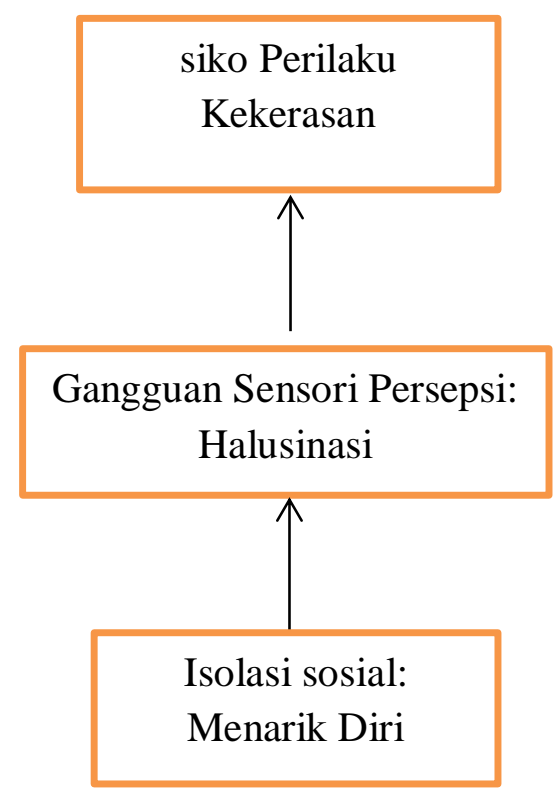

\subsection{Diagnosa Keperawatan}

1. Gangguan persepsi sensori:Halusinasi : Pendengaran

2. Resiko perilaku kekerasan

3. Isolasi Sosial 


\subsection{Intervensi Keperawatan}

\begin{tabular}{|c|c|c|}
\hline No & Diagnosa Keperawatan & Intervensi \\
\hline 1 & $\begin{array}{l}\text { Gangguan persepsi sensori : } \\
\text { Halusinasi pendengaran dan } \\
\text { penglihatan }\end{array}$ & \begin{tabular}{|l} 
SP 1: \\
1. Mengidentifikasi isi, frekuensi, \\
waktu terjadi, situasi pencetus, \\
perasaan dan respon halusinasi \\
2. Mengontrol halusinasi dengan \\
caramenghardik \\
SP 2 : \\
Mengontrol \\
halusinasi dengan \\
cara minum obat \\
secara teratur \\
SP 3 : \\
Mengontrol halusinasi dengan \\
bercakap-cakap dengan orang lain \\
SP 4 : \\
Mengontrol halusinasi dengan \\
melakukankegiatan terjadwal
\end{tabular} \\
\hline 2 & Resiko perilaku kekerasan & $\begin{array}{l}\text { SP 1: } \\
\text { Mengontrol PK dengan cara : } \\
\text { a) Latihan fisik } 1 \text { : Tarik nafas } \\
\text { dalam } \\
\text { b) Latihan fisik } 2 \text { : Pukul kasur } \\
\text { bantal } \\
\text { SP 2 : } \\
\text { Mengontrol PK dengan cara minum } \\
\text { obat secara teratur. } \\
\text { SP 3 : } \\
\text { Komunikasi secara verbal } \\
\text { Asektif/berbicara baik-baik. } \\
\text { SP } 4 \text { : } \\
\text { Spiritual. }\end{array}$ \\
\hline
\end{tabular}




\begin{tabular}{|c|c|c|}
\hline 3 & Isolasi Sosial & 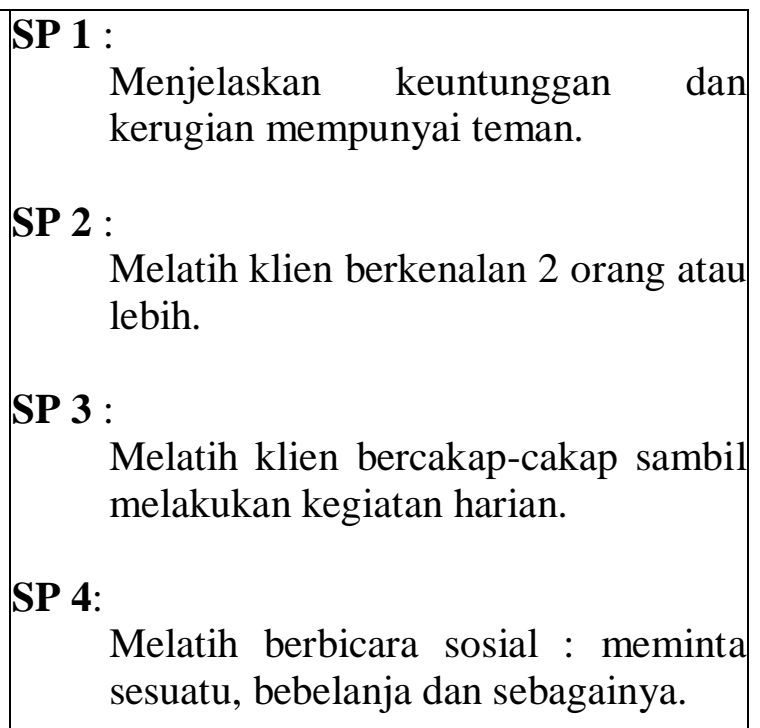 \\
\hline
\end{tabular}




\subsection{Implementasi dan Evaluasi}

\begin{tabular}{|c|c|c|}
\hline Hari/Tgl & Implementasi & Evaluasi \\
\hline $\begin{array}{l}\text { Sabtu/06- } \\
03-2021\end{array}$ & $\begin{array}{l}\text { 1. Data } \\
\text { 1. Keluarga mengatakan klien } \\
\text { sering berbicara sendiri dan } \\
\text { tertawa sendiri } \\
\text { 2. Klien sering mendengar } \\
\text { suara- suara yang seperti } \\
\text { mengajak dan menyuruh } \\
\text { hapir setiap hari. } \\
\text { 3. Klien terkadang menangis } \\
\text { ketika mendengar suara- } \\
\text { suara yang ia dengarkan. } \\
\text { 4. Klien sering mendengar } \\
\text { suara- suara ketika pagi hari } \\
\text { sekitar pukul 02.00 Wib } \\
\text { 2. Diagnosa Keperawatan : } \\
\text { Gangguan persepsi sensori : } \\
\text { Halusinasi pendengaran. } \\
\text { Tindakan } \\
\text { Keperawatan : } \\
\text { SP 1 : } \\
\text { a. Mengidentifikasi isi, } \\
\text { frekuensi, waktu terjadi, } \\
\text { situasi pencetus, perasaan } \\
\text { dan respon halusinasi } \\
\text { b. Mengontrol halusinasi } \\
\text { dengan cara menghardik } \\
\text { secara teratur }\end{array}$ & 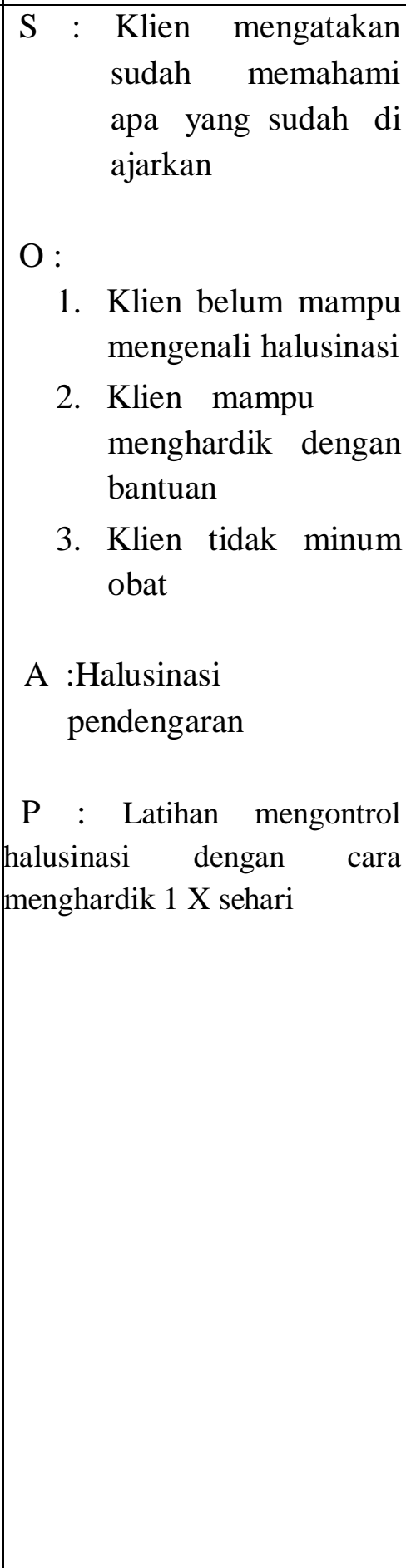 \\
\hline & $\begin{array}{l}\text { 4. Rencana } \quad \text { Tindak } \\
\text { Lanjut : }\end{array}$ & \\
\hline
\end{tabular}




\begin{tabular}{|c|c|c|}
\hline & $\begin{array}{l}\text { SP 3 : } \\
\text { Mengontrol halusinasi dengan } \\
\text { bercakap-cakap dengan orang } \\
\text { lain } \\
\text { SP 4 : } \\
\begin{array}{l}\text { 1. Mengontrol halusinasi } \\
\text { dengan melakukan kegiatan } \\
\text { terjadwal }\end{array}\end{array}$ & \\
\hline $\begin{array}{l}\text { Senin/08- } \\
03-2021\end{array}$ & $\begin{array}{l}\text { 1. Data } \\
\text { a. Keluarga mengatakan klien } \\
\text { sering berbicara sendiri dan } \\
\text { tertawa sendiri } \\
\text { b. Klien sering mendengar } \\
\text { suara- suara yang seperti } \\
\text { mengajak dan menyuruh } \\
\text { hapir setiap hari. } \\
\text { c. Klien terkadang menangis } \\
\text { ketika mendengar suara- } \\
\text { suara yang ia dengarkan. } \\
\text { d. Klien sering mendengar } \\
\text { suara- suara ketika pagi } \\
\text { hari sekitar pukul 02.00 } \\
\text { Wib } \\
\text { 2. Diagnosa Keperawatan : } \\
\text { Gangguan persepsi sensori : } \\
\text { Halusinasi pendengaran } \\
\text { 3. Tindakan } \\
\text { Keperawatan : } \\
\text { Mengontrol halusinasi dengan } \\
\text { ber bercakap-cakap dengan } \\
\text { oranglain }\end{array}$ & 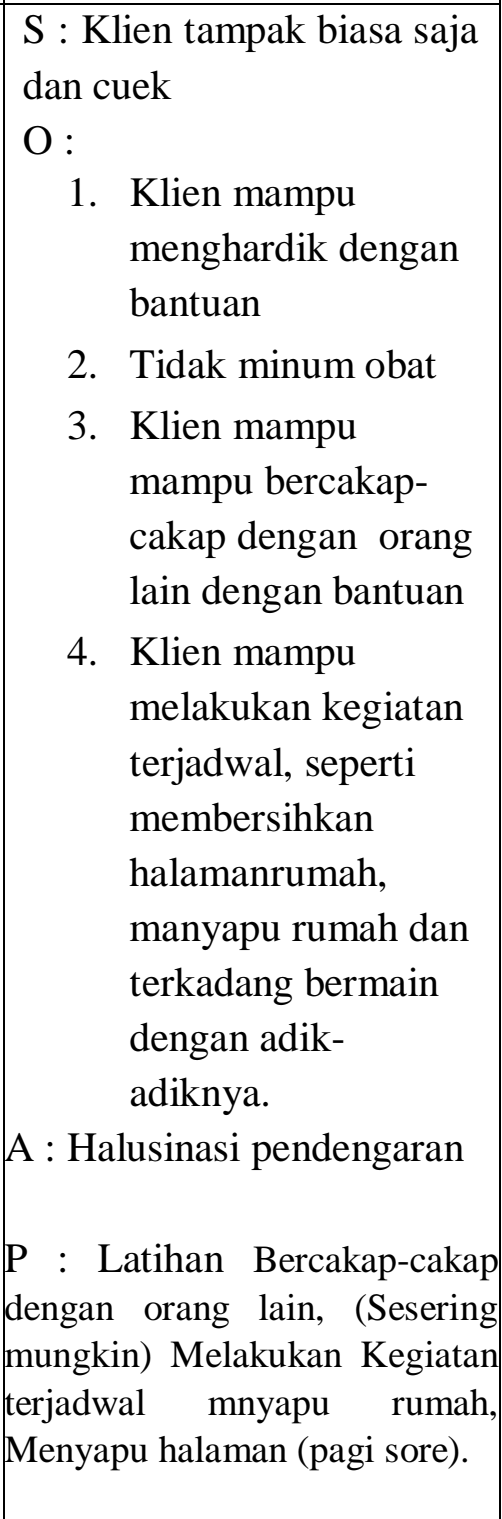 \\
\hline
\end{tabular}




\begin{tabular}{|c|c|c|}
\hline & \begin{tabular}{|l} 
SP 4 : \\
\\
$\quad$ Mengontrol halusinasi \\
\\
denganmelakukan kegiatan \\
terjadwal \\
4. Rencana Tindak Lanjut : \\
Memberikan kembali terapi SP \\
1- SP 4
\end{tabular} & \\
\hline $\begin{array}{l}\text { Jumat/11- } \\
\text { 03-2021 }\end{array}$ & $\begin{array}{l}\text { 1. Data } \\
\text { 1. Keluarga mengatakan klien } \\
\text { sering berbicara sendiri dan } \\
\text { tertawa sendiri. } \\
\text { 2. Klien sering mendengar } \\
\text { suara- suara yang seperti } \\
\text { mengajak dan menyuruh } \\
\text { hapir setiap hari. } \\
\text { 3. Klien terkadang menangis } \\
\text { ketika mendengar suara- } \\
\text { suara yang ia dengarkan. } \\
\text { 4. Klien sering mendengar } \\
\text { suara- suara ketika pagi hari } \\
\text { sekitar pukul 02.00 Wib. } \\
\text { 2. Diagnosa Keperawatan : } \\
\text { Gangguan persepsi sensori : } \\
\text { Halusinasi pendengaran. } \\
\text { 3. Tindakan Keperawatan } \\
\text { SP 1 : } \\
\text { 1) Mengidentifikasi } \\
\text { frekuensi, waktu terjadi, } \\
\text { situasi pencetus, perasaan } \\
\text { dan respon halusinasi } \\
\text { dengan cara menghardik }\end{array}$ & 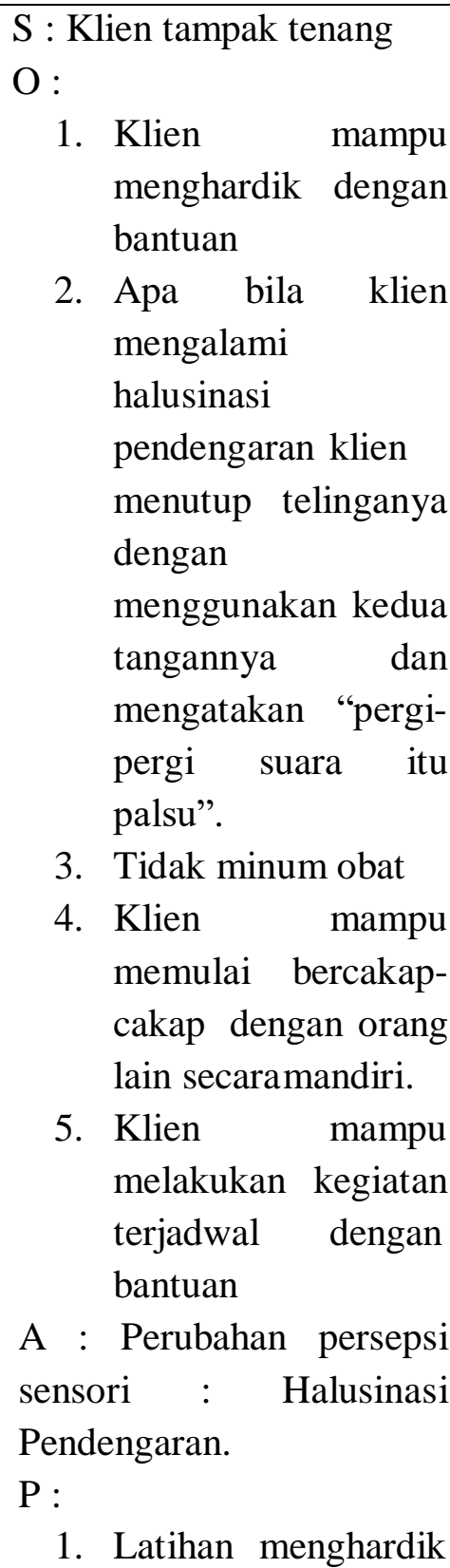 \\
\hline
\end{tabular}




\begin{tabular}{|c|c|c|}
\hline & $\begin{array}{l}\text { SP } 2 \text { : } \\
\text { Mengontrol halusinasi dengan } \\
\text { cara minum obat secara teratur } \\
\text { 4. Rencana Tindak Lanjut : } \\
\text { SP 3 : } \\
\text { Mengontrol halusinasi dengan } \\
\text { bercakap-cakap dengan orang } \\
\text { lain } \\
\text { SP } 4 \text { : } \\
\text { Mengontrol halusinasi dengan } \\
\text { melakukan kegiatan terjadwal }\end{array}$ & $\begin{array}{l}\text { halusinasi } 2 \text { kali } \\
\text { sehari } \\
\text { 2. Latihan Bercakap- } \\
\text { cakap dengan orang } \\
\text { lain } 2 \text { kali sehari }\end{array}$ \\
\hline $\begin{array}{l}\text { Sabtu/14- } \\
03-2021\end{array}$ & $\begin{array}{l}\text { 1. Data } \\
\text { 1. Keluarga mengatakan klien } \\
\text { sering berbicara sendiri dan } \\
\text { tertawa sendiri. } \\
\text { 2. Klien sering mendengar } \\
\text { suara- suara yang seperti } \\
\text { mengajak dan menyuruh } \\
\text { hapir setiap hari. } \\
\text { 3. Klien terkadang menangis } \\
\text { ketika mendengar suara- } \\
\text { suara yang ia dengarkan. } \\
\text { 4. Klien sering mendengar } \\
\text { suara- suara ketika pagi hari } \\
\text { sekitar pukul } 02.00 \text { Wib } \\
\text { Diagnosa Keperawatan : } \\
\text { Gangguan persepsi sensori : } \\
\text { Halusinasi pendengaran } \\
\text { 3. Tindakan } \\
\text { Keperawatan : } \\
\text { MP 3 : } \\
\text { Mengontrol halusinasi dengan } \\
\text { lain orakap-cakap dengan orang }\end{array}$ & $\begin{array}{ll}\text { S : } & \text { Klien tampak tenang } \\
\text { O : } & \\
\text { 1. } & \text { Klien mampu } \\
& \text { menghardik dengan } \\
& \text { mandiri. } \\
\text { 2. } & \text { Apa bila klien } \\
& \text { mengalami } \\
& \text { halusinasi } \\
& \text { pendengaran klien } \\
& \text { menutup kedua } \\
& \text { telinga dengan } \\
& \text { menggunakan kedua } \\
& \text { tangan dan } \\
& \text { mengatakan "pergi- } \\
& \text { pergi suara itu } \\
& \text { palsu”. } \\
\text { 3. } & \text { Klien sudah mau } \\
& \text { minum obatsecara } \\
& \text { teratur lagi. } \\
\text { 4. } & \text { Klien mampu } \\
\text { memulai bercakap- } \\
\text { cakap dengan orang } \\
\text { lain dan mulai bisa } \\
\text { berinteraksi. } \\
\text { 5. } \\
\text { melien mampu } \\
\text { terjadwal seperti } \\
\text { halamanrumah }\end{array}$ \\
\hline
\end{tabular}




\begin{tabular}{|c|c|c|}
\hline & $\begin{array}{l}\text { SP 4 : } \\
\text { Mengontrol halusinasi dengan } \\
\text { melakukan kegiatan terjadwal } \\
\text { Rencana Tindak Lanjut : Follow } \\
\text { up dan evaluasi SP 1-Sp4 } \\
\text { Gangguan persepsi sensori : } \\
\text { Halusinasi pendengaran }\end{array}$ & \begin{tabular}{|l}
\multicolumn{2}{|c|}{ dengan motivasi } \\
A : Perubahan persepsi \\
sensori : Halusinasi \\
pendengaran \\
P : \\
1. \\
Latihan menghardik \\
halusinasi 2 kali \\
sehari \\
2. \\
Latihan Bercakap- \\
cakap dengan orang \\
lain 2 kali sehari. \\
3. \\
Latihan Melakukan \\
kegiatan terjadwal 1 \\
kali sehariyaitu \\
menyapu halaman \\
rumah.
\end{tabular} \\
\hline $\begin{array}{l}\text { Senin 16- } \\
\text { Maret } \\
2021\end{array}$ & \begin{tabular}{|l} 
1. \\
klien tidak mampu kooperatif \\
dengan orang lain \\
2. klien mengatakan tidak \\
pernah bergaul dengan seke- \\
lilingnya dan klien menutup \\
diri \\
Diagnosa Keperawatan : Isolasi \\
Sosial \\
Intervensi Keperawatan \\
SP 1 \\
a. Mengidentifikasi penyebab \\
isolasi sosial \\
b. Berdiskuksi tentang keun- \\
tungan dan kerugian dalam \\
berinteraksi dengan orang lain \\
c. Mengajarkan klien
\end{tabular} & $\begin{array}{l}\text { S : klien merasa senang saat } \\
\text { mau diajak berkenanlan } \\
\text { dengan orang lain. } \\
\text { O : Klien mampu melakukan } \\
\text { cara berkenanlan dengan satu } \\
\text { orang } \\
\text { A : Isolasi sosial (+) } \\
\text { P } \quad \text { Latihan berkenalan } \\
\text { dengan satu denga teman }\end{array}$ \\
\hline
\end{tabular}




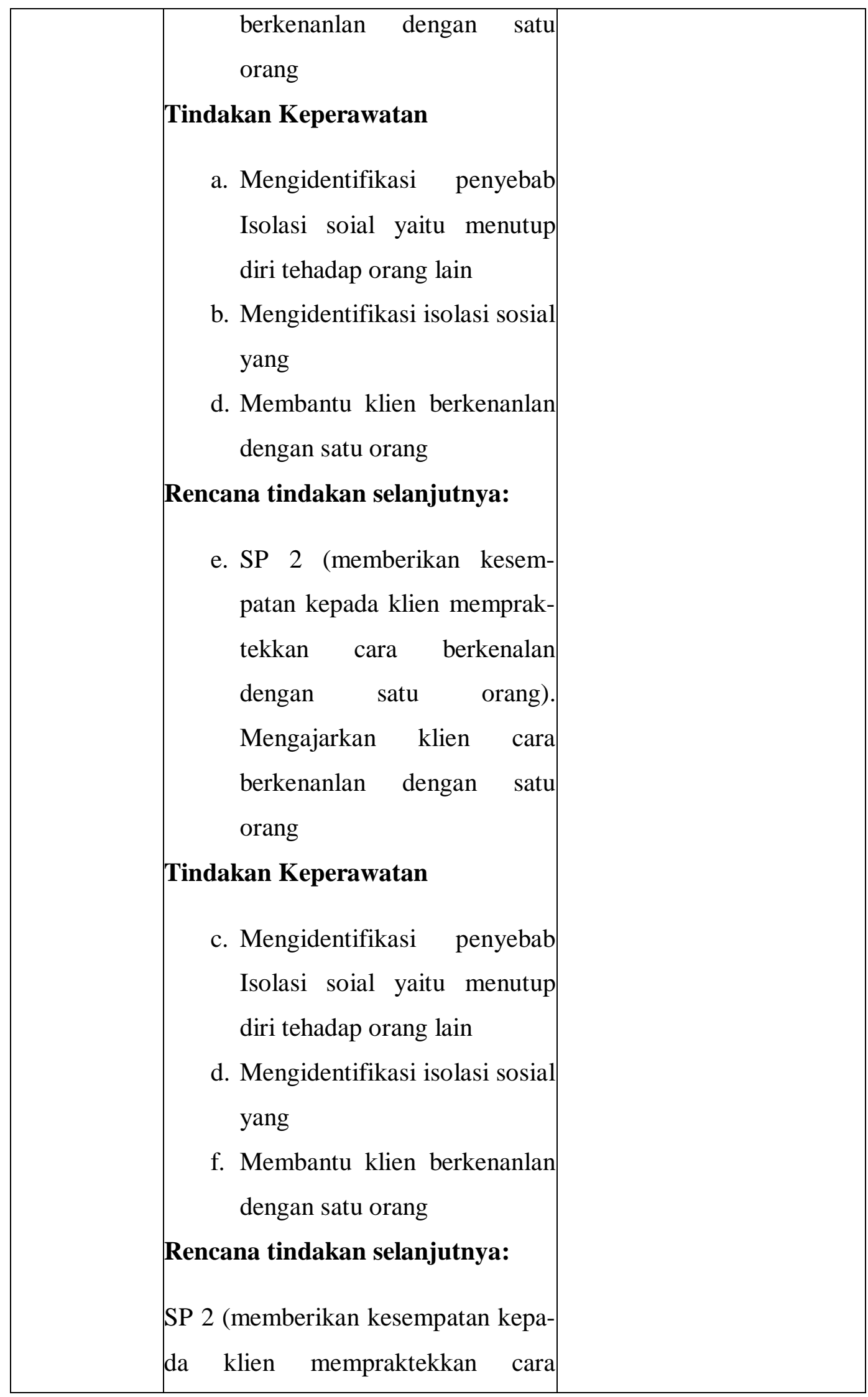




\begin{tabular}{|c|c|c|}
\hline & berkenalan dengan satu orang). & \\
\hline $\begin{array}{l}\text { Rabu 14- } \\
\text { Maret 2021 }\end{array}$ & 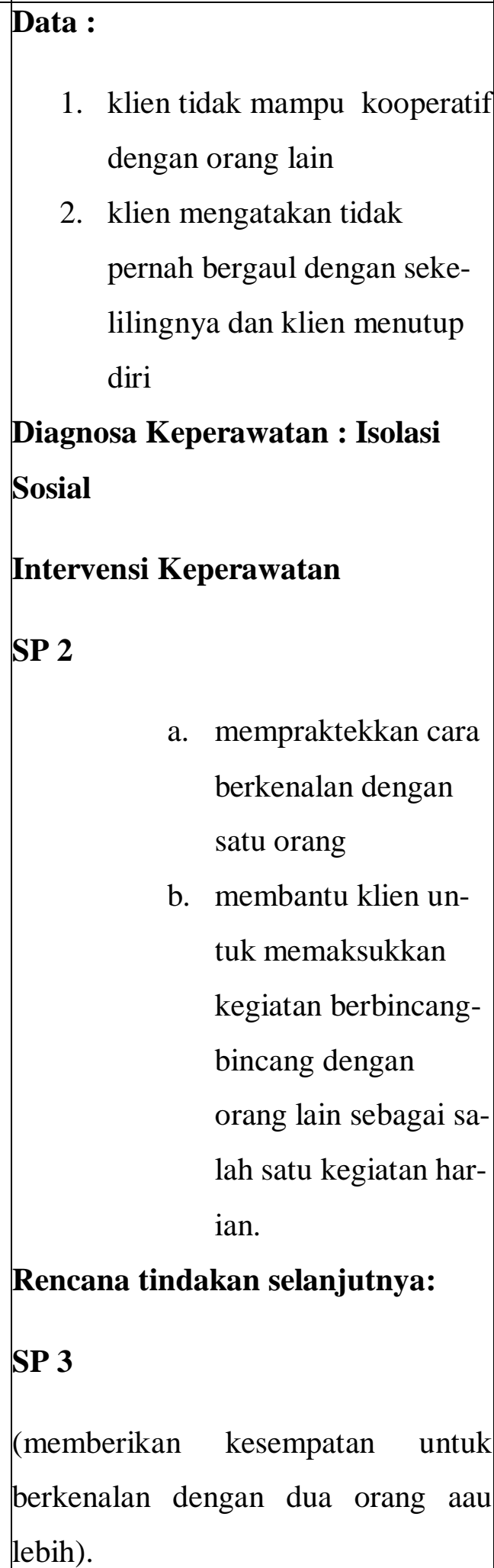 & $\begin{array}{l}\text { S : klien mengatakan mau } \\
\text { berkenalan dengan tetangga.. } \\
\text { O : Klien mampu melakukan } \\
\text { cara berkenanlan dengan satu } \\
\text { dan dua orang } \\
\text { A : Isolasi sosial (+) } \\
\text { P : Ltihan berkenalan dengan } \\
\text { orang-orang disekitarnya dan } \\
\text { memasukkan dalam jadwal } \\
\text { kegiatan harian. }\end{array}$ \\
\hline
\end{tabular}




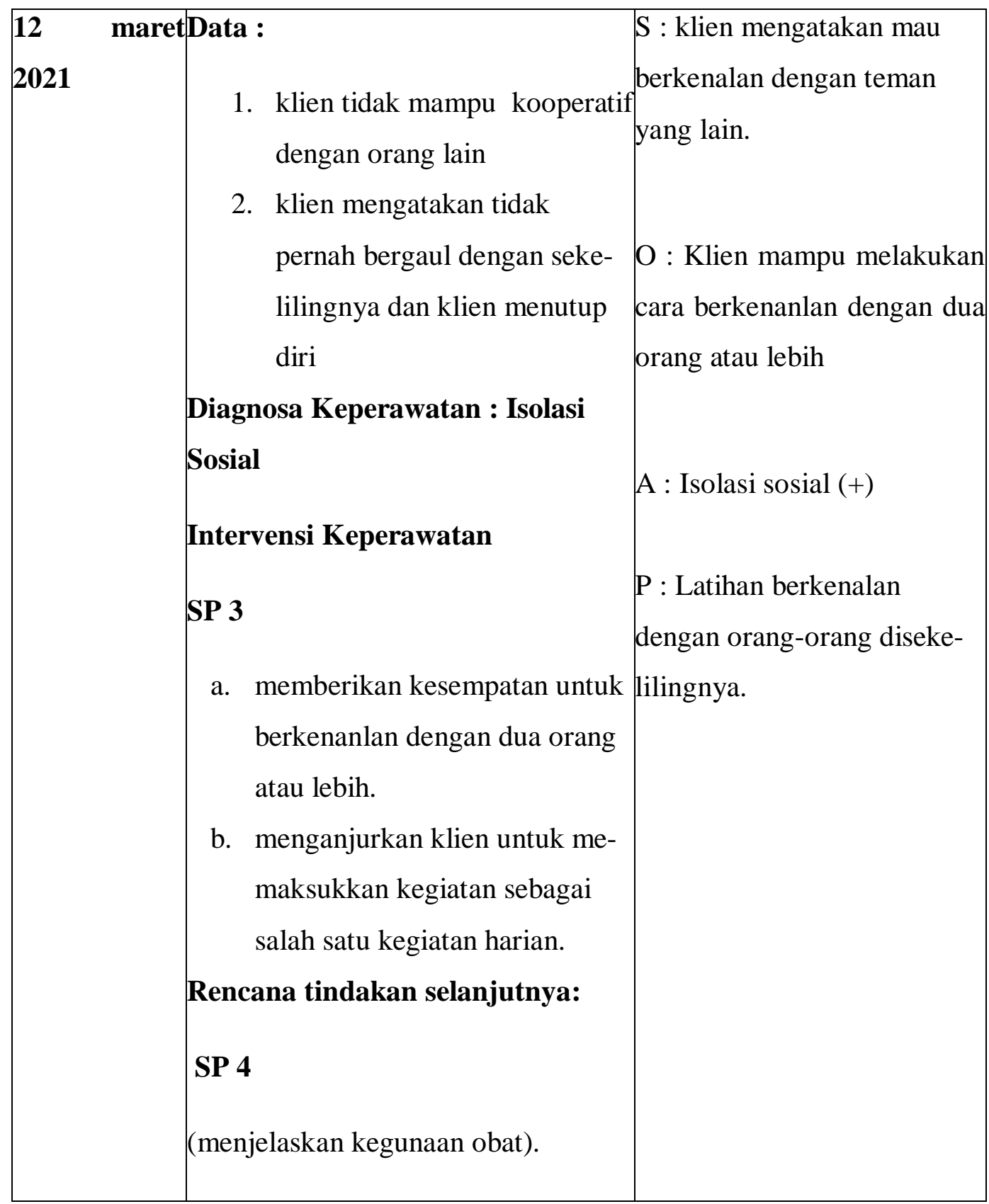




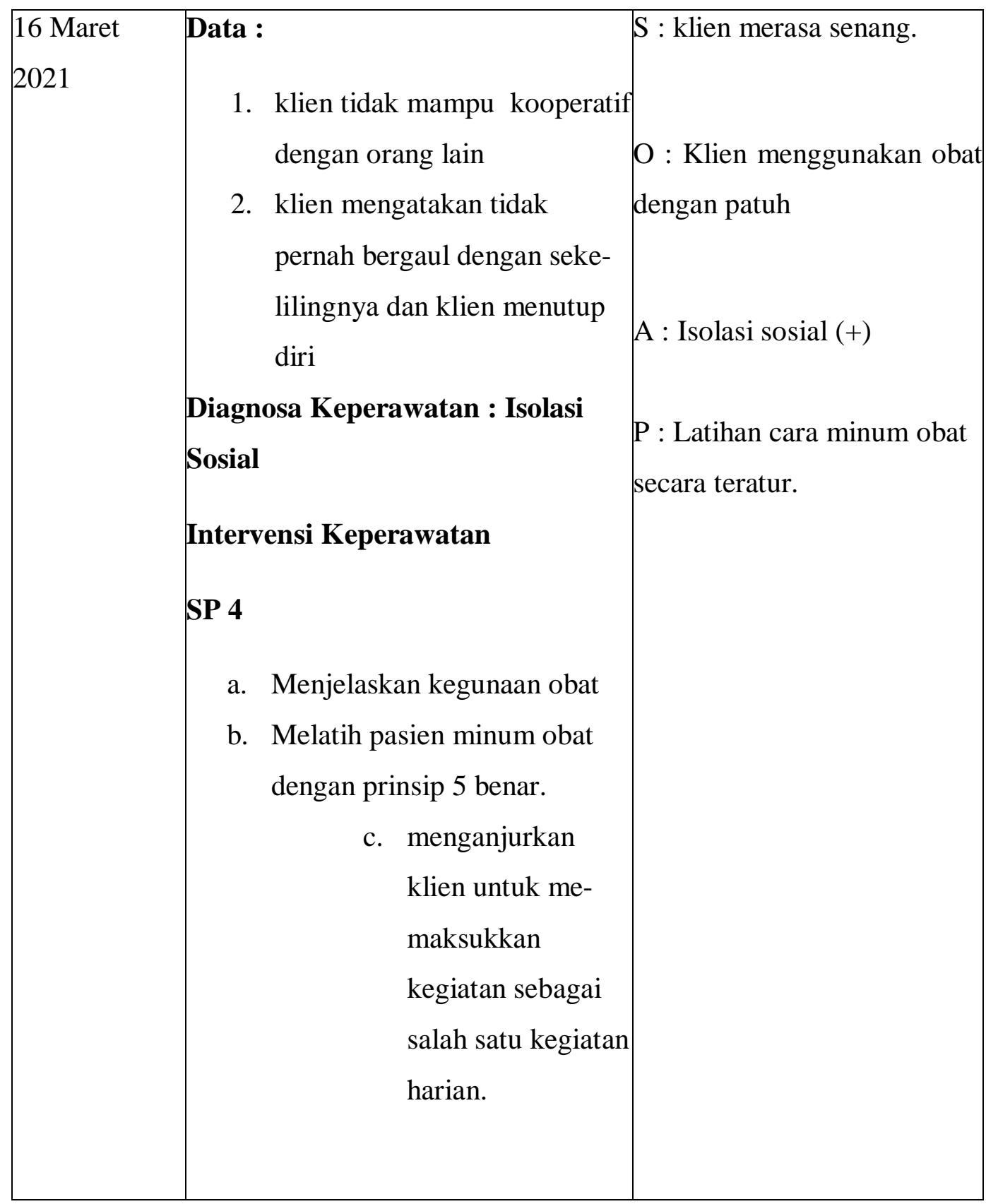




\section{BAB 4 \\ BAB PEMBAHASAN}

Setelah penulis melaksanakan asuhan keperawatan kepada Ny. M dengan gangguan sensori persepsi: halusinasi diJalan Lizadri Putra, Kecamatan Medan Tuntungan, maka penulis pada $\mathrm{BAB}$ ini akan membahas kesenjangan antara teoritis dengan tinjauan kasus. Pembahasan dimulai melalui tahapan proses keperawatan yaitu pengkajian, diagnosa keparawatan, perencanaan, pelaksanaan dan evaluasi.

\subsection{Pengkajian}

Pada pembahasan ini diuraikan tentang hasil pelaksanaan tindakan keperawatan dengan pemberian terapi generalis pada klien halusinasi pendengaran. Pembahasan menyangkut analisis hasil penerapan terapi generalis terhadap masalah keperawatan halusinasi pendengaran. Tindakan keperawatan didasarkan pada pengkajian dan diagnosis keperawatan yang terdiri dari tindakan generalis yang dijabarkan sebagai berikut :

Tahap pengkajian pada klien halusinasi dilakukan interaksi perawat-klien melalui komunikasi terapeutik untuk mengumpulkan data dan informasi tentang status kesehatan klien. Pada proses pengkajian, data penting yang perlu didapatkan adalah jenis dan isi halusinasi, waktu, frekuensi, dan situasi yang menyebabkan halusinasi, respons terhadap halusinasi (Keliat dkk, 2016).

Selama pengkajian dilakukan pengumpulan data dari beberapa sumber, yaitu dari pasien dan keluarga pasien. Maka penulis melakukan pendekatan kepada pasien dan keluarga pasien melalui komunikasi terapeutik yang lebih terbuka membantupasien untuk memecahkan perasaannya dan juga melakukan observasi kepada pasien.

Adapun upaya tersebut yaitu:

a. Melakukan pendekatan dan membina hubungan saling percaya diri padaklien agar klien lebih terbuka dan lebih percaya dengan menggunakan perasaan. Mengadakan pengkajian klien dengan wawancara

b. Dalam pengkajian ini, penulis menemukan kesenjangan karena ditemukan. Pada 
kasus Ny. M, Klien sering mendengar suara-suara aneh, mondar-mandir, terkadang tertawa dan tersenyum sendiri, menangis bahkan berteriak dan lain-lain. Gejala gejala yang muncul tersebut tidak semua mencakup dengan yang ada di teori klinis dari halusnasi (Keliat, 2014). Akan tetapi terdapat faktor predisposisi maupun presipitasi yang menyebabkan kekambuhan penyakit yang dialami oleh Ny. M.

Tindakan keperawatan terapi generalis yang dilakukan pada Ny. M adalah strategi pertemuan pertama sampai pertemuan empat. Strategi pertemuan pertama meliputi mengidentifikasi isi, frekuensi, jenis, dan respon klien terhadap halusinasi serta melatih cara menghardik halusinasi. Strategi pertemuan kedua yang dilakukan pada Ny. M, meliputi melatih cara mengendalikan dengan bercakap-cakap kepada orang lain. Strategi pertemuan yang ketiga adalah menyusun jadwal kegiatan bersama-sama dengan klien. Strategi pertemuan keempat adalah mengajarkan dan melatih Ny. M cara minum obat yang teratur.

\subsection{Diagnosa Keperawatan}

Diagnosa keperawatan merupakan suatu penilaian klinis mengenai respons klien terhadap masalah kesehatan atau proses kehidupan yang dialaminya baik yang berlangsung aktual maupun potensial. Diagnosis keperawatan bertujuan untuk mengidentifikasi respons klien individu, keluarga dan komunitas terhadap situasi yang berkaitan dengan kesehatan (Fadhillah, 2017). Diagnosa yang muncul pada kasus Ny. M yang meliputi: halusinasi, Resiko kekerasan.Isolasi Sosial. Dari hal tersebut di atasdapat dilihat terjadi kesamaan antara teori dan kasus. Dimana semua diagnosa pada teori muncul pada kasus Ny. M.

\subsection{Implementasi}

Implementasi atau disebut tindakan keperawatan merupakan rangkaian perilaku atau aktivitas yang dikerjakan oleh perawat untuk mengimplementasikan intervensi keperawatan. Tindakan-tindakan pada intervensi keperawatan terdiri atas observasi, 
terapeutik, edukasi dan kolaborasi (Fadhillah, 2018). Pada tahap implementasi, penulis hanya mengatasi 1 masalah keperawatan yakni: diagnosa keperawatan halusinasi. Pada diagnosa keperawatan gangguan persepsi sensori halusinasi dilakukan strategi pertemuan yaitu mengidentifikasi isi, frekuensi, waktu terjadi, perasaan, respon halusinasi. Kemudian strategi pertemuan yang dilakukan yaitu latihan mengontrol halusinasi dengan cara menghardik. Strategi pertemuan yang kedua yaitu anjurkan minum obat secara teratur, strategi pertemuan yang ke tiga yaitu latihan dengan cara bercakap-cakap pada saat aktivitas dan latihan strategi pertemuan ke empat yaitu melatih klien melakukan semua jadwal kegiatan.

\subsection{Evaluasi}

Setelah tindakan keperawatan, segera lakukan evaluasi. Evaluasi terhadap masalah keperawatan halusinasi meliputi kemampuan Klien halusinasi dan keluarganya dan kemampuan perawat dalam merawat Klien halusinasi (Keliat, 2012). Pada tinajauan teoritis evaluasi yang diharapkan adalah: Klien mempercayai perawat sebagai terapis, Klien menyadari bahwa yang dialaminya tidak ada objeknya, dapat mengidentifikaasi halusinasi, dapat mengendalikan halusinasi melalui menghardik, latihan bercakap-cakap, melakukan aktivitas sertamenggunakan obat secara teratur. Klien mampu mengontrol dan mengidentifikasi halusinasi, Klien mampu melakukan latihan bercakap-cakap dengan orang lain, Klien mampu melaksanakan jadwal yang telah dibuat bersama, Klien mampu memahami penggunaan obat yang benar:. Selain itu, dapat dilihat dari setiap evalusi yang dilakukan pada asuhan keperawatan, dimana terjadi penurunan gejala yang dialami oleh $\mathrm{Ny}$. M dari hari kehari selama proses interaksi. 


\section{BAB 5 PENUTUP}

\subsection{Kesimpulan}

Berdasarkan uraian pada pembahasan di atas, maka penulis dapat menyimpulkan bahwa :

1. Pengkajian dilakukan secara langsung pada klien dan juga dengan menjadikanstatus klien sebagai sumber informasi yang dapat mendukung data-data pengkajian. Selama proses pengkajian, perawat mengunakan komunikasi terapeutik serta membina hubungan saling percaya antara perawat-klien. Pada kasus Ny. M diperoleh bahwa klien mengalami gejala-gejala halusinasi seperti mendengar suarasuara, gelisah, sulit tidur, mondar-mandir,tidak dapatmempertahankan kontak mata, mudah marah dan lain-lain. Faktor predisposisi Ny. M yaitu tidak mengalami gangguan jiwa sebelumnya.

2. Diagnosa keperawatan yang muncul pada kasus Ny. M Halusinasi pendengaran, koping individu inefektif, regimen teraupetikkeluarga inefektif, dan terjadi Resiko kekrasan dan hingga mengalami Isolasi Sosial. Tetapi pada pelaksanaannya, penulis fokus pada masalah utama yaitu halusinasi pendengaran..

3. Perencanaan dan implementasi keperawatan disesuaikan dengan strategi pertemuan pada pasien halusinasi pendengaran dan penglihatan.

4. Evaluasi diperoleh bahwa terjadi peningkatan kemampuan klien dalam mengendalikan halusinasi yang dialami serta dampak pada penurunan gejala halusinasi pendengaran yang dialami.

\subsection{Saran}

\section{Bagi Perawat}

Diharapkan dapat menerapkan komunikasi terapeutik dalam pelaksanaan strategi pertemuan 1-4 pada klien dengan halusinasi sehingga dapat mempercepat proses pemulihan klien.

\section{Bagi Institusi Pendidikan}

Dapat meningkatkan bimbingan praktek lapangan kepada mahasiswa profesi ners sehingga mahasiswa semakin mampu dalam melakukan asuhan keperawatan pada 
pasien-pasien yang mengalami halusinasi.

\section{Bagi Pasien}

Laporan ini diharapkan dapat menjadi acuan dan referensi dalam memberikan asuhan keperawatan pada klien dengan halusinasi pendengaran. 


\section{DAFTAR PUSTAKA}

1. Cressela, U. (2020). Asuhan Keperawatan Jiwa Dengan Gangguan Sensori Persepsi: Halusinasi Pendengaran Pada Kasus Skizofrenia Terhadap Ny. R Di Ruang Melati Rs Jiwa Daerah Provinsi Lampung. Poltekkes Tanjungkarang. http://repository.poltekkestjk.ac.id/1988/

2. Damaiyati (2014), Asuhan Keperawatan jiwa, Pt Refika Aditama: Bandung

3. Dalami E ,dkk. (2014) . Asuhan Keperawatan Klien dengan Gangguan Jiwa. Jakarta: CV Trans Info Media.

4. Emulyani, E. (2020). Pengaruh Terapi Zikir Terhadap Penurunan Tanda Dan Gejala Halusinasi Pada Pasien Halusinasi.Health Care: Jurnal Kesehatan,9(1), 17-25. https://doi.org/10.36763/healthcare.v9i1.60

5. Fadhillah H. (2017). Standar Diagnosis Keperawatan Indonesia. Jakarta Selatan: DPP, PPNI

6. Fadhillah H. (2018). Standar Intervensi Keperawatan Indonesia. Jakarta Selatan: DPP, PPNI

7. Feri, K. (2020). Asuhan Keperawatan Dengan Pemberian Terapi Musik Klasik Terhadap Mengontrol Halusinasi Pada Pasien Halusinasi Pendengaran Dengan Menggunakan Metode Studi Literature. KTI, Universitas Muhammadiyah Tasikmalaya. Http://Repository.Umtas.Ac.Id/105/

8. Keliat B. A, dkk. (2016). Keperawatan Kesehatan Jiwa Komunitas. Jakarta: EGC

9. Keliat B. A, dkk. (2016). Keperawatan Kesehatan Jiwa Komunitas. Jakarta: EGC

10. Keliat B. A, dkk. (2014). Proses Keperawatan Jiwa Edisi II. Jakarta: EGC.

11. Keliat B. A, Akemat. (2012). Model Praktik Keperawatan Profesional Jiwa. Jakarta: EGC.

12. Nurdiana, N. (2020). Penerapan Terapi Spiritual: Dzikir Pada Tn. A Terhadap Kemampuan Mengontrol Halusinasi Pendengaran Di Ruangan Nuri RSJ Prof. HB Saanin Padang. Universitas Perintis Indonesia. http://repo.stikesperintis.ac.id/id/eprint/1190

13. Pardede, J. A., Irwan, F., Hulu, E. P., Manalu, L. W., Sitanggang, R., \& Waruwu, J. F. A. P. (2021). Asuhan keperawatan Jiwa Dengan Masalah Halusinasi. doi: 10.31219/osf.io/fdqzn 
14. Pima Astari, U. P. I. K. (2020). Studi Literatur: Asuhan Keperawatan Pada Penderita Skizofrenia Dengan Masalah Keperawatan Halusinasi Pendengaran. Universitas Muhammadiyah Ponorogo. http://eprints.umpo.ac.id/id/eprint/6192

15. Pardede, J. A., \& Siregar, R. A. (2016). Pendidikan Kesehatan Kepatuhan Minum Obat Terhadap Perubahan Gejala Halusinasi Pada Klienskizofrenia. Mental Health, 3(1).

16. Prabowo, E. (2014). Konsep \& Aplikasi Asuhan Keperawatan Jiwa. Yogyakarta: Nuha Medika

17. Pardede, J. A. (2017). The Implementation of Family Tasks with The Frequency of Recurrence of Social Isolation Patients. Mental Health, 4(2).

18. Prakoso, A. D., \& Herliawati, H. (2020). Aplikasi Keperawatan Jiwa Pada Pasien Halusinasi Pendengaran Dan Penglihatan Dengan Terapi Psikoreligius Di Rsj. Ernaldi Bahar Palembang Provinsi Sumatra Selatan. Sriwijaya University. https://repository.unsri.ac.id/30248/

19. Putri, V. S., \& Trimusarofah, T. (2018). Pengaruh Penerapan Strategi Pelaksanaan Keluarga Terhadap Kemampuan Keluarga Merawat Pasien Halusinasi Di Kota Jambi Tahun 2017. Jurnal Akademika Baiturrahim Jambi,7(1), 17-24. http://jab.stikba.ac.id/index.php/jab/article/view/57

20. Pima, A. (2020). Studi Literatur: Asuhan Keperawatan Pada Penderita Skizofrenia Dengan Masalah Keperawatan Halusinasi Pendengaran. Universitas Muhammadiyah Ponorogo. http://eprints.umpo.ac.id/6192/

21. Pardede, J. A. (2020). Family Burden Related to Coping when Treating Hallucination Patients. Jurnal Ilmu Keperawatan Jiwa, 3(4), 453-460. http://dx.doi.org/10.32584/jikj.v3i4.671

22. Restia Putri, E. M. A. (2020). Asuhan Keperawatan Pada Pasien Skizofrenia Dengan Masalah Keperawatan Halusinasi Penglihatan Di Rumah Sakit Jiwa Surakarta Dr. Arif Zainudin Surakarta (Doctoral dissertation, Universitas Muhammadiyah Ponorogo). http://eprints.umpo.ac.id/id/eprint/6127

23. Pardede, J. A., Keliat, B. A., \& Wardani, I. Y. (2013). Pengaruh Acceptance And Commitment Therapy Dan Pendidikan Kesehatan Kepatuhan Minum Obat Terhadap Gejala, Kemampuan Berkomitmen Pada Pengobatan Dan Kepatuhan Pasien Skizofrenia. Tesis. FIK UI. Depok 